\title{
Narrating islands: fragmentation and totality as figures of thought in Raoul Schrott's work
}

\author{
Oriana Schällibaum \\ University of Zurich, Switzerland \\ oriana.schaellibaum@uzh.ch
}

\begin{abstract}
This paper reflects on depictions of islands in two novels by the Austrian author Raoul Schrott (born 1964): his first novel, Finis Terrae: Manuscripts, from 1995, and the later Tristan da Cunha or Half of the Earth from 2003. I argue that Schrott's concepts and explorations of islands strongly influence the presentation and organisation of his texts. Finis Terrae and Tristan da Cunha exhibit distinctly different concepts of the insular. Whereas the earlier text accentuates a frail, fragmented, and almost mythical condition, the later novel Tristan evokes a plethora of Western topoi about islands and heavily relies on dualities. In both cases, island concepts are also reflected in narrative gestures: oppositions are central to interpreting and analysing Tristan da Cunha, and Finis Terrae revolves around fragmentation, vagueness, and loss. Islands are thus not only objects in the texts - they also determine the design and structure of the texts.
\end{abstract}

Keywords: Austria, contemporary literature, factuality, fiction, intertextuality, islands, narrative strategies, utopia

https://doi.org/10.24043/isj.21

(C) 2017 - Institute of Island Studies, University of Prince Edward Island, Canada.

\section{Introduction}

In this paper, I examine depictions of islands in the Austrian author Raoul Schrott's novels Tristan da Cunha oder Die Hälfte der Erde (Tristan da Cunha or Half of the Earth) and Finis Terrae. Ein Nachlass (Finis Terrae: Manuscripts). While Schrott's writing does not at first seem to deal with questions about the authority of representation or to challenge Western island discourse, it nevertheless contributes to a discussion of these issues. I claim that Schrott addresses and transforms traditional island discourses in an interesting way. Not only do his novels display the entire Western cultural history of islands, but the sheer plethora of meanings also subverts this history. Finis Terrae and Tristan da Cunha can be shown to offer distinctly different concepts of the insular. Schrott's concepts and explorations of islands strongly influence the presentation and organisation of his texts. Both novels accordingly offer different modes of narration, despite their structural similarities. The island is thus not just a subject or theme in Schrott's writing; rather, its conception is reflected in his texts' structures.

This paper is divided into six parts. First, I will introduce Raoul Schrott. Second, I will briefly sketch the plot of the 2003 novel Tristan da Cunha. In the third section, I will then unfold the diverse semantic layers of the island in this text, namely its geographic, symbolic, and metaphorical meanings. Throughout this paper, the term 'geographic' will be used to indicate a reference to the real. It goes without saying that the islands of the novels are, strictly speaking, fictional since they are presented through the medium of the book. In the fourth section, my focus will be on the tension between Tristan's orientation toward a stable centre on the one hand and clear oppositions on the other, a feature that has been overlooked in scholarly work so far. In the fifth section, I will outline the 1995 novel Finis Terrae and compare its conceptions of the 
insular to those in Tristan. Finally, in the conclusion, I will discuss my interpretations and place them in a greater context.

\section{Raoul Schrott: the temptation of the real}

Deserts, ultima Thule, white spots on the map: the award-winning Austrian poet, author, and translator Raoul Schrott (born in 1964) likes to explore frontiers. Origins particularly fascinate him, whether they are literary, cultural, or geological beginnings (Schrott, 2016). The seductive call of the real (and, notably, of the sciences) permeates his writing. Schrott, who grew up in Austria, Switzerland, and Tunisia, is also a devoted traveler. In 2005, he published an adventurous report about "holding a piece of ancient earth" in his hands in northwestern Canada (Schrott, 2005; all translations are my own unless otherwise noted). In 2007 he took part in an expedition to one of the "last empty places" on earth (Schrott, 2007) in the tri-border region of the Sudan, Chad, and Lybia. Furthermore, his poems nearly always carry a date and a location-most evidently in the collection Hotels - which suggests authenticity and an identifiable moment in the life of the author. The emphasis lies on 'suggests', though, as these dates often appear to be part of a multilayered play with meanings. This can be seen in Tropen: Über das Erhabene (Tropics: On the Sublime) or Die Kunst an nichts zu glauben (The Art of Believing in Nothing; see Schällibaum, 2016). Similarly, his much-noted (and often-criticised) 2008 study on Homer's origins, in which he identifies Homer as a Cilician poet and traces the events of the Iliad back to historical incidents, relies on his own visits to the sites. In conclusion, physical space and real topography are of great importance to Schrott's writing.

\section{Tristan da Cunha or Half of the Earth: the poetics of remoteness}

Unsurprisingly, Schrott's novel Tristan da Cunha or Half of the Earth, published in 2003, is primarily about a group of volcanic islands of the same name in the South Atlantic Ocean-and not about the early modern Portuguese explorer Tristão da Cunha. Over 2,400 kilometres from the nearest continent, the archipelago is the world's most remote group of inhabited islands. The main island of the group also bears the name Tristan da Cunha. Sparsely populated with a current population of roughly 300, it has often been invoked as an archaic remnant, an "island out of time" (Booy, 1958, p. 196), and studied by linguists (Schreier, 2003).

The polyphonic 700-page novel does not, however, limit itself to the island as a geographic entity. It is, rather, also concerned with social space, with the organisation of society. Additionally, it describes the island as an inherently prefigured space shaped by literature. Despite being replete with accurate historical and scientific information as well as eyewitness accounts, which, however, are not explicitly labeled as such, Tristan da Cunha is not a documentary text. Nor does it represent a crude attempt at mapping and thus recovering reality. Above all it highlights the possibilities of narration and the underlying material of narration. It presents the narrative act as both affirmatively historical and aware of its own artificiality. The material "is the protagonist of the novel," says Rüdiger Görner in his (rather crushing) review (Görner, 2004, p. 91). Indeed, the book aims at reconstructing "a world in a nutshell" (Schrott, 2006). In the libretto that accompanies the novel, Schrott (2003a, p. 6) explains how he envisioned the island as an "Archimedean point" on which "one could lever the world." The island thus becomes a symbol of human interactions, passions, and "existential revolt."

The twenty chapters are divided into four narrative threads. First, there is the South African scientist Noomi Morholt, who spends a few months at the Antarctic research base SANAE IV. The journal she keeps there is presented in four parts. The first part serves as the prologue of the novel and the last part as the epilogue. In addition to Noomi, another narrative voice appears in the same thread in the form of letters: Rui is a great great grandson of the famous Brazilian author Euclides da Cunha and also a writer himself. Rui had a short affair with Noomi and is now writing to her via e-mail. 
In her journal, Noomi recounts finding a boxful of books, which was supposed to be sent to the island Tristan. In the box, there is also a "bundle wrapped in a wax cloth" that contains notebooks (by Christian Reval), letters (by Edwin Heron Dodgson), and a book bound in leather (by Mark Thomsen) (Schrott, 2003b, p. 23; Schrott's Tristan da Cunha is subsequently cited as $\mathrm{TdC}$ ). These texts then constitute the three other strands of the narrative. The act of finding texts in a chest or box alludes to the traditional adventure genre. It can be read as an ironic wink by Schrott. While in the past, the literary strategy of 'authorial disavowal' was sometimes used to substantiate claims of authenticity and thus avoid the criticism of fiction (Davis, 1983), in postmodern fiction it results in the opposite effect (Grimm-Hamen, 2009, p. 236).

The four narrative threads are organised by an implied hierarchy: Noomi is not on the same level as the other narrators since she reads and comments on their texts. It is important to note, however, that the reader of the novel does not follow her reading process: "I have begun reading Thomsen's micrograms [...] somewhere in the middle [...], I am not reading the sheets in order" (TdC, pp. 580-81), she states quite late in the novel. In contrast, Thomsen's writing is presented in chronological order in Schrott's novel.

In the box, Noomi finds books on the history of the island, such as Peter A. Munch's Crisis in Utopia and Augustus Earle's Narrative of a Residence on the Island of Tristan d'Acunha, and "three books by and about Lewis Carroll, Darwin's treatise on the origin of species and his journal from the voyage on the Beagle as well as the Pléiade edition of the romances about Tristan and Iseult, a novel by Euclides da Cunha, Dante's epic, and a handbook for priests" (TdC, p. 22). Noomi (and probably also the reader) think of it as a "strange selection." "But not much remained from the Library of Alexandria either-and perhaps a whole world could be reconstructed from these books as well," she says (TdC, pp. 22-23). Here, Noomi programmatically formulates the novel's aspiration. Starting with its very first appearance, Tristan is portrayed as a mediated object. It is a textual island, and a "literary stage of utopia" (Grimm-Hamen, 2014, p. 63).

It is quite obvious that the books that Noomi finds are also used by Schrott as intertextual sources for the novel. But the material is handled in many different ways. Some texts are woven into the book across many pages, such as the long excerpts from Earle's report or da Cunha's Os Sertões (translated into English as Rebellion in the Backlands). Others are just mentioned. There are many allusions to the Tristan legend. Some episodes even clearly mirror the old narrative.

The second strand features the surveyor Christian Reval. It is told backwards in time, spanning from 1960 to 1942, beginning with the deaths of Reval and his wife on Gough Island, which lies about 400 kilometres southeast of Tristan. In this narrative, the legend of Tristan and Iseult is omnipresent: While crossing the ocean, Christian Reval, a young man from Cornwall, falls in love with the Irishwoman Marah. He is supposed to bring her to her future husband on the island of Tristan, where Reval starts to work as a radio operator. Despite engaging with Reval, Marah does not leave her husband Marcus. Reval soon leaves the island, but comes back several times and tries to reconnect with Marah. Reval finally marries Maria, the sister of his colleague. The text's focus on Maria's slim, white fingers makes it clear that she is the equivalent of Iseult of the White Hands from the legend.

The third narrative is composed of letters by Edwin Heron Dodgson, a priest on Tristan Island at the end of the 19th century. Dodgson, a brother of the famous Lewis Carroll, was indeed stationed on Tristan as a priest by the Society for the Propagation of the Gospel in Foreign Parts. While some historical letters and reports by Dodgson have been preserved, most of the letters in the novel are fictitious. During his stay on the island, the fictional Dodgson falls in love with a girl named Marah and subsequently becomes trapped in a dangerous spiral of guilt, jealousy, and insanity.

Last of all, Mark Thomsen, a philatelist, writes the history of the Tristan archipelago using his stamp collection. But he increasingly blends his own ancestral story and marital break-up into the history. His wife Marah has left him for another philatelist, the Dutchman van Houten- "he could have been my nephew," Mark writes (TdC, p. 92). Here it is impossible not to hear Marke, the cuckold in the Tristan and Iseult myths. 
In all of these constellations, the beloved woman is called Marah. The biblical reference is made explicit when Noomi tells Rui that she wants to be called Marah (TdC, p. 327) (Noomi's second name is Maria) (Schutti, 2005): After having lost her husband and sons, the biblical Naomi, which means pleasant and agreeable in Hebrew, says, "Call me Mara, because the Almighty has made my life very bitter" (Ruth 1:20).

\section{Island discourses in Tristan da Cunha}

Besides the female figure of Marah, the other object of desire is Tristan Island. The novel's men want to discover, explore, possess, govern, educate, or leave it. At the centre of this yearning, there is, however, not only the geographic island of Tristan, but also a plethora of semantic layers. In the following, I will illustrate the various meanings of the insular in Tristan da Cunha.

First, let me explain the island's unifying effect on the text. Tristan da Cunha is the centre of the novel because it connects the four threads. Noomi uses a geometrical figure to illustrate this: "When I read the handwriting of these three notebooks and then think about myself writing, it is as if we formed the four corners of a square. And Rui was in the middle [...]; better would be the island instead of him" (TdC, pp. 684-85). In an interview, Schrott expresses this thought as his own view (Niedermeier, 2003). Indeed, the island is the text's multilayered centre. Its meanings quickly change from literal to allegorical and symbolic, from scientific to imaginary. Tristan is defined by (Western) discourses on islands and topoi that range from the political, social, and anthropological to the colonial, economical, and mythical. Schrott proves once more to be an erudite and well-read author (he habilitated at the University of Innsbruck in 1996), who feels at home in a variety of discourses. Critics, however, have not always enjoyed this ostentatious display of erudition.

On the one hand, Mark Thomsen's micrograms tell the story of the island's discovery and settlement. As Gillis (2004, p. 3) says, "atlantic islands and mainlands are not internally coherent, clearly bounded things, but interdependent parts of a larger world." Only by adopting a broad geographic and historical perspective can we "avoid essentializing the distinction between islands and continents" and reveal their reciprocal shaping through historical interaction. In Thomsen's writing, the island serves as a stage where the world powers make their appearances, one after another. Oddly enough, even Austria figures among the countries that took the stage on the island for a short period of time. In 1775, Guillaume Bolts landed on Tristan and took possession of it for Emperor Joseph II. This 'story of impostors' is likely to have pleased Schrott (2003a, p. 13). In this respect, Grimm-Hamen (2013, pp. 118-19) refers to how post-war isolationist Austria stylised itself as the 'Island of the Blessed': "Tristan da Cunha might be an allegory for a peripheral Austria, which for a long time believed itself to be the centre of the world."

On the other hand, the island is also prominent as a geographic or real space. The description of the harsh weather, the challenging conditions of living, the dangerous cliffs, and the dominating volcano counteract the paradisiac imaginary often associated with islands. But it also becomes clear that this insular space is only accessible in mediated form. The many implicit quotes and allusions to literary works suggest that culture colours personal experience. The subjective is always accompanied by the supra-individual and allegorical (Grimm-Hamen, 2011). This literary influence becomes especially visible with respect to the idea of the island as a utopian space: islands have long been considered ideal places to test forms of government; they are microcosms for social experiments (see Höppner, 2007).

The novel thus seems to install the island as the stable centre of the text. In the following, I argue, however, that the text's main momentum does not stem from a reliable centre, but rather that antagonistic forces pervade throughout the novel which challenge the focal perspective. I believe that these oppositions are central to analysing the text. Nonetheless, they are commonly overlooked or downplayed by scholars in favour of unity and totality. In the following, I will identify and explain six oppositional pairs (A-F). 


\section{Oppositional structures in Tristan da Cunha}

A. The first opposition deals with the status of Tristan Island as the centre of the text. Constellations and conflicts repeat themselves, provoking an irritating effect of déjà vu. Vague hints of connections are scattered throughout the text: Reval has family on Tristan (TdC, p. 626). He reads Dodgson's letters (TdC, pp. 529, 531). A colleague of his is Thomsen's younger brother (TdC, p. 52). He made stamp designs that collectors are desperately looking for (TdC, p. 529). Furthermore, a member of Noomi's team also collects stamps (like Thomsen) (TdC, p. 16). These evocations do not seem to be motivated by the narration. They do not elucidate each other either. The dense network of links between the strands indicates that the island is merely an artificially designed centre. This narrative strategy contributes to the underlying unity of the composition, At the same time it paradoxically destabilises the unity.

In addition, Grimm-Hamen (2009, p. 234) emphasises the fragmented character of the narrative. She speaks of a "fallacious unity, ostentatiously exhibited" through the various correspondences throughout the novel. But the fragmented, polyphonic narration is part of Schrott's program of the authentic. He has repeatedly stated that he tried to "reflect the complex tectonic of the real in a novel" (Widmann, 2011); that he uses letters, diaries, and fragmentary notes to achieve the "most authentic" effect, which leads him to include things that are contingent and seemingly contradictory (Schrott, 2003a, pp. 21-22). According to Grimm-Hamen (2011), the form of the text suggests an inherent failure of its claim to totality. In support of her assertion, she points out that connections are often identified by the reader only in retrospect, and underlines the irritations and confusions that occur while reading. Instead of speaking of 'failure' (the authentic is not a failure), I highlight the tension between the claims to unity and fragmentation.

B. On the level of the characters, Noomi is conceived as a counter-figure to the three men (or four, if we include Rui). She is the only female voice in the text that articulates her own view. The figure of Marah is always described from a male perspective. While all the protagonists are designed to contrast with each other (Niedermeier, 2003), their difference to Noomi is even more pronounced. This is also manifest in the tension between the depictions of Antarctica and Tristan. Whereas the volcanic island is a place of projections, Antarctica is so white and flat that she "could draw the vanishing lines of an illusory perspective on it, but nothing would be able to be projected with them," Noomi observes (TdC, p. 12, emphasis is mine). And Rui states that only artificial survival is possible in Antarctica, while on Tristan human beings take a stand against nature as the "most extreme form of existence" (TdC, pp. 571-72). The same idea is reflected in Noomi's statement that the South Pole is a place "where people cannot live, only survive" (TdC, p. 706). The Antarctic continent is "without history," she adds, and thus "faceless" (TdC, p. 581). In German, the paronomasia between geschichtslos and gesichtslos emphasises the opposition between the two expressions. To her, the three men appear to write as if they wore a mask (TdC, p. 569 , p. 580). But wearing a mask still displays more human traits than having no face at all, being devoid of any distinguishing features.

C. The contrast between the island as a place of longing and as the scene of harsh, ordinary life constitutes a third, distinct opposition. The utopian concepts are shown to fail unavoidably (Höppner, 2007, p. 39), and it is Schrott's outspoken intention to deconstruct any idealisation by comparing it to reality (Niedermeier, 2003). As Gillis (2004, p. 1) notes, "it is not real islands that are irresistible, but the idea of the island that is the true source of Western islomania."

D. At first, the novel's title appears rather opaque. Its discriminating function, however, is noteworthy: the use of the world half (Hälfte) instead of middle, for instance, induces an opposition, a ripping through the earth, splitting it into two parts.

E. Another opposition is based on the affinity to factuality: Fact and fiction constitute opposite poles in the novel. The 700-page book clearly aims at a comprehensive narrative that offers a historic, genealogical, and utopian view of the island (while also telling individual stories). Interestingly, Tristan da Cunha has also been dubbed an almost baroque encyclopaedia (Breitbarth, 
2010) of geography, geodesy, meteorology, physics, and biology, as well as nautical science, philately, and theology. While I agree that the book contains specialised knowledge and sometimes uses specific, almost scientific language, I reject its identification as a documentary work that could be used as a compendium on the basis of the credibility of the "knowledge which is accumulated in the novel" (Breitbarth, 2010, p. 348). Certainly, in an interview, Schrott insists: "All facts that are enounced in the book are real" (Niedermeier, 2003) — which sounds intriguingly familiar: when editor's fictions were popular, fictional biographies have often made the claim "that all the Facts herein recited, are literally true," such as in the preface of The Matchless Rogue: or ... Newgate Tom from 1725 (Adams, 1983, p. 90). But how do we know what is a fact? We only know if we check. If we do not, we are left guessing, facing an ambiguous text. The characters themselves emphasise the uncertain status of the written text: Noomi realises that one constructs one's own past by mingling fact and fiction (TdC, p. 707), and Thomsen admits he has added some anecdotes to the history of Tristan and omitted some others (TdC, p. 449). We can understand these remarks as metafictional.

F. As the sixth and last example, I will explain the doubling of the author's voice, which results in an intriguing dichotomy.

The character Rui has often been seen as Schrott's alter ego, an assumption that is strengthened by the alleged integration of the author's own childhood memories into Rui (see TdC, p. 571; Schrott, 2003a, p. 5). But one should note that Schrott has also inscribed himself into other characters. His own trip to Tristan is mirrored in Noomi's short stay on the island (TdC, pp. 581-87, 688; Schrott, 2003, p. 17), and Thomsen's Irish residence 'Bishop's Luck' (TdC, p. 376) seems to have been Schrott's home while he wrote the novel on the island of Tristan. (One can infer this because the penultimate page of Tristan carries the inscription 'Cappaghglass' (TdC, no number), and another book by Schrott explicitly mentions 'Bishop's Luck' in addition to 'Cappaghglass' (Schrott \& Dall'O, 2001, p. 148).) Traces of the real author can be found everywhere in Tristan.

It has been argued that one might think of Tristan da Cunha as the book Rui is writing throughout the novel, creating a narrative metalepsis (Breitbarth, 2010; Kühnel, 2013). Noomi had announced, after all, that she would send him her notes after her stay in Antarctica (TdC, p. 700). But the fictional dates in the novel do not confirm this reading. In May/June 2003, Noomi writes down that she will send Rui her notes after her stay at the research station ends in six more months, but Schrott publishes the actual novel at the end of August 2003. Additionally, Rui already reads from his manuscript in the book (TdC, p. 712), and he states that his "hero" shows traces of the adventurer Lambert and the painter Earle (TdC, p. 572).

Scholars have also applied Rui's poetological statements about his own writing to the novel. I do not contest this view-correspondences can be seen, for example, when Rui asserts similarities between life on Tristan and in the Brazilian backcountry, which is depicted in da Cunha's Os Sertões (TdC, p. 573), or when he talks about adopting foreign textual material (TdC, p. 572) - but I argue that many of these passages are to be read with irony, such as when Rui and Noomi discuss the title of his novel, which he thinks should be called "Tristan da Cunha [...], but that name makes it sound like a historical tome [...]; Tristan alone, in contrast, sounds like Wagner and a romance that promises to not have a happy end, and a title like The Loneliest Island in the World is only good for the American public: I will call it The Tempest" (TdC, p. 343). Moreover, Rui's memory is unreliable. Craving recognition, he merely recycles stories: "this is also what I do 'in real life'; tell stories that I have half forgotten-or that I find in other people's books" (TdC, p. 332). In a pretentious manner, he utters psychoanalytical catchwords:

And an island is from the outset allegorical - ultimately for everything, for happiness and death: a symbol for the water that surrounds it, the air in which it is exposed to the winds, the fire of the sun that determines its time, the earth that it is. Inaccessible in the middle of the ocean. An emblem of the unconscious and the mythical image of the woman, the 
virgin, and the mother - or whatever we men project onto her; why else have I become a writer if not for this Eros? [...] The search for the origins of the world and one's own self so as to find salvation - the most antediluvian principle of writing that there is. (TdC, p. 573)

It is hard not to read this as persiflage, as mockery. Additionally, in contrast to Schrott's view of Tristan Island as an "Archimedean point," Rui says that he does not want to "make a flyspeck on a map the middle of [his] world allegory" (TdC, p. 343). Rui states that:

the difference between a good and a bad writer is, as I have read somewhere, that the bad one borrows while the good one steals-because art consists in hiding the stolen goods within one's own lines so that they fit together, are inconspicuous, and as if from one pen. (TdC, p. 572)

This reads like a riposte that Schrott has directed at his critics who often reproach him for adopting textual material without referencing it (see Schmitz-Emans, 2004). In fact, in an interview in 2009, Schrott is confronted with the assertion that he himself said this phrase and embraces the idea (Böhlau, 2009, p. 429). The saying (and variations of it) is common, and its origins are (not without irony) somewhat hard to determine. For instance, the aphorism "good artists copy; great artists steal" is commonly attributed to Picasso (e.g. Farago, 2014). T. S. Eliot (1920, p. 114) is sometimes named as Picasso's source: "Immature poets imitate; mature poets steal; bad poets deface what they take, and good poets make it into something better, or at least something different." When Rui prefaces this phrase with "I have read somewhere," he demonstrates the exact act it describes, namely taking someone else's ideas. But his statement has a comical touch. By making his plagiarism explicit, his words are, by his own definition, "borrowed" and not "stolen."

The text exhibits, however, another, more serious author function. Noomi writes: "But no one is an island, as they say, all for one's self, everyone is part of a continent, be it even this dark one here" (TdC, p. 685). This is a reference to John Donne's famous words (1987, p. 87): "No man is an Iland, intire of it selfe; every man is a peece of the Continent, a part of the maine." Noomi continues:

Death inside all of us; all writing to admit it to ourselves. As if these notebooks were by one author and from one book, the pages torn out of it to translate them into another language, again and again. (TdC, p. 685; emphasis mine to highlight differences between Donne's and Noomi's texts)

We can compare this to the following lines from Donne's Meditation 17, which, incidentally, are the novel's motto: "All mankinde is of one Author, and is one volume; when one Man dies, one Chapter is not torne out of the booke, but translated into a better language; and every Chapter must be so translated" (Donne, 1987, p. 86).

Again Noomi:

The history of the island, which was once real until it became a chapter, from which each of them [Dodgson, Reval, Thomsen] took whole paragraphs, sometimes altering them a little to inscribe themselves into them, some sentences with the handwriting of age or sickness, but the leaves would not be collected into one volume; they lie loose next to each other. (TdC, p. 685)

Donne (1987, p. 86), for his part, reads:

God emploies several translators; some peeces are translated by Age, some by sicknesse [...]; but Gods hand is in every translation; and his hand shall binde up all our scattered leaves againe, for that Librarie where every booke shall lie open to one another. 
Dante's La Divina Commedia, which is a continuous reference in Tristan, can also be heard here. In Canto XXXIII, lines 85-87, the scattered pages or leaves, an allusion to the dispersed leaves of the sibyl, are bound together by (divine) love: "In its depths I saw contained, / by love into a single volume bound, / the pages scattered through the universe" (Hollander, 2007, p. 823; "Nel suo profondo vidi che s'interna, / legato con amore in un volume, / ciò che per l'universo si squaderna”). Comparing Noomi's statement to Dante and Donne, one notes the flagrant absence of God. According to Noomi, the pages written about the island are not translated into a better language, and there is no mighty hand that gathers the leaves and binds them together. Yet the opposite appears to be the case for the novel's readers: The notebooks have been bound together in the medium of the book that the reader holds in his or her hands. The passage thus suggests the existence of a godlike author who has arranged the pages.

By these means, the miniature texts in between the sections, which mostly describe the island's landscapes and stormy weather, can also be attributed to an author: the creator of the book, the one who bound the pages together. Here, as in the table of contents, one finds a propensity to aesthetic structuring. Zeyringer (2005, p. 153) observed that "with one exception, the novel's twenty long sections start with an I like island, Isolde or with an M like mundus, Marah." But I count five exceptions: they begin four times with an ' $E$ ' and one time with an 'R'. Each miniature text starts with 'IM' (German for in) in oversize capital letters. Combined with the capital letters at the beginning of each section, they form variations on the word IMMER (always) and IM MEER (in the sea).

This evidence (the examples A-F) suggests that, besides offering a focal point of longing and unity, the novel Tristan da Cunha strongly highlights oppositions. A mode of reading that focuses on unity and completeness overlooks the antagonistic forces in the text. Many of the patterns of order and gestures of totality are just promises - they are circumvented and betrayed again and again.

Islands are often understood through oppositional categories: "earth and water, land and sea, continental and insular, big and small, enclosed and open, close and remote, connected and secluded" (Dautel \& Schödel, 2016, p. 11). But these categories are culturally conditioned and rooted in occidental island discourse. As Moser (2005, p. 408) puts it: "These oppositions are rooted even more deeply in Western thought since they deny having been conditioned by culture and appear to articulate given natural circumstances." Nevertheless, islands can be seen as genuine double entities: they unify opposite poles (Meistersheim 1997, p. 113). This paradoxical figure could be seen as an essence of insularity - without essentialising the otherness of islands. Tristan da Cunha treats this understanding of islands in a subtle way. The island is thus manifest throughout the novel— not only on the level of content but also, more generally, in the text's structure.

\section{Finis Terrae: endings, frontiers, fragments}

At this point we turn to Schrott's first novel, Finis Terrae. Manuscripts from 1995. The two texts have multiple features in common: Finis Terrae also has four narrative threads. The protagonists also seem to have a preference for faraway, forlorn landscapes and a desire for (final) frontiers, both real and metaphorical. Finis Terrae also incorporates factual material, and, last but not least, islands play an important part in it as well.

Finis Terrae is supposedly a collection of manuscripts organised into four notebooks. The first book claims to be the newly found notes of Pytheas of Massalia, who managed to sail to Thule in the fourth century AD. The second book consists of copies of letters and journal entries documenting the fatally ill Ludwig Höhnel's journey following Pytheas's path from Portugal to Cornwall. In the third book, Höhnel writes about his difficult (erotic) relationships with Schiaparelli, and, later, with his wife, who, in an incestuous twist, turns out to be Schiaparelli's sister. Finally, the fourth notebook is a montage of reports from various times about Lake Rudolf (today Lake Turkana) in northern Kenya. 
Pytheas's narrative amalgamates a variety of sources into the illusion of an authentic text without explicitly crediting them. On his periplus, Pytheas visits many islands close to the shore. On these islands, Pytheas encounters rituals and burials, miraculous events, and forbidden land, reserved only for the gods. The islands along the shore represent a transitional zone: they are no longer the mainland, but they are still part of the inhabitable world, maintaining a border to the wide, open sea, full of danger. The notion of an ending, of an ultimate limit, lingers behind each of them. But the islands also limit the worldviews of their inhabitants, as is made explicit in Pytheas's statement about the Heboudes: "The islands that mean the end of the world for them are called the Heboudes" (Schrott, 1995, p. 57; Finis Terrae is cited subsequently as FT for clarity). Pytheas then finally turns away from the coast and makes islands his anchor points, shifting the finis terrae, the end of the world, always one step further until he reaches Thule (which lives forth in the saying ultima thule). Pytheas's conclusion that "beyond the oikoumene is the Okeanos, but beyond the Okeanos is the void" (FT, p. 83) is later exemplified by the textual material: as the sentence is repeated, 'the void' is filled with vertical lines, characterising the text as a fragment (FT, p. 95).

In the second book, Höhnel follows Pytheas's journey, trying to identify the islands he sees with places from Pytheas's narrative. Interestingly enough, his observations are also fragmentary, e.g.: "If it were the island where Pytheas dropped anchor [the rest of the sentence is illegible]" (FT, p. 115). He often comments on the coast, the meeting of land and sea, and describes it with metaphors of violently cut-open bodies, thus making it analogous to his illness and suffering:

the trailing rolling waves [...], a ball of tearing and ripped tendons, like the fibres of a hardened muscle bursting under the pressure of the wind, the rigid blade of the waves peeling off the muscle's grey skin with one swipe. (FT, pp. 160-61)

In the third notebook, Höhnel narrates his encounter with the archaeologist Schiaparelli at an excavation on the shores of Lake Rudolf. He got the trainee position because of his grandfather, Chevalier Höhnel, who 'discovered' the lake along with the Teleki expedition:

Lake Rudolf. As if the beginning of my story lay there, somewhere in the steel engravings in my grandfather's book, $[\ldots]$ and in the story of South Island, which I gathered little by little. (FT, p. 174)

The excavation finds remains of a special hominid species, which they dub homo rudolfensis. With the notion of Kenya's Rift Valley as the cradle of humanity and a reproduction of Courbet's L'origine $d u$ monde that shows a close-up of a woman's vagina in Höhnels notebooks, the text makes it clear that it is trying to get to the origin of something-be it psychological, existential, or even universal.

Excerpts about South Island are compiled in the fourth notebook. In Lake Turkana there are several volcanic islands, one of which is called South Island (sometimes referred to as Höhnel Island, although Chevalier Höhnel never set foot on it). According to a legend of the Elmolo tribe, its existence can be traced back to a pregnant herdswoman (FT, p. 248). The woman shifted a stone at a source, which led to a tremendous flooding. She managed to save herself and her goats on a mountain, which then became South Island. Cut off from her community, she and her son procreated. The island is described as being difficult to reach: the passage is dangerous and the lava makes it impassable at points. The reports from various times focus on two men of an expedition in the 1930s led by Fuchs (Fuchs et al., 1935) who disappeared on the island under mysterious circumstances that have never been explained. This recalls Reval's death on Gough Island. His death, however, is anchored in the Tristan myth and incorporated into a greater pattern of meaning. It is a rejection of the myth's ultimate union in death. The island thus becomes an arcane centre of events surrounding the disappearance of the two men from Fuchs's expedition. The editor brings up the hypothesis that the locations mentioned in the manuscripts form a parabola on the map, with the focus on Lake Turkana. 
The island does not posit a stable centre for the story, though — any framework of meaning implodes. The island seems to have its own laws. Surprisingly, the explorers find domestic goats and traces of humans on the island. But the Elmolo assert "that neither they nor their ancestors have ever set foot on the island and that they have no desire to do so" (FT, p. 247). Although the leaders and also reporters try to make sense of the disappearance of the two men, gathering traces of them and analysing weather and drift conditions, they ultimately fail to obtain a satisfying explanation. The anthropologist Mirzeler (2006) has shown that the Elmolo believe that the herdswoman Sepenya, from whom they descend, killed the two men from Fuchs's expedition as a ritual sacrifice. The British are believed to have murdered her and her son as a consequence of this. Since that time, the Elmolo assume that they are "crossbreeds" because the white men's blood mingled with Sepenya's blood. But the Elmolo perspective and their mythical explanation are not reported in the novel. The mystery remains unsolved. No explanatory story can be told. Modern technology and reason fail in front of the archaic power of the island. What remains at the end of the book is a void: all attempts to make sense dissolve. It is another end of the world, not one at the edge, but at its centre-maybe even at its origin.

Looking at spatial movements, we observe that the focus of the narrated space in Finis Terrae moves inward from the outer frontiers toward a hollow centre. Pytheas's route in the first book proceeds north along the coastline. Since his logbook is a fragment, his traces vanish somewhere up in the far north. Höhnel is reported missing from a hotel in Cornwall, his journey ends at the liminal - the frontier of life and death, land and sea. The third part takes place at the shores of Lake Rudolf: we approach the island. At the same time, Höhnel gets closer to his childhood memories and the origins of his infatuation with Schiaparelli. The text becomes even more disparate, elusive, and vague, only to culminate in an uncommented assemblage of factual fragments about explorations of the mysterious, deserted Lake Rudolf and South Island. Additionally, the editor of Höhnel's manuscripts repeatedly doubts the veracity of the account. The search for meaning, for a valid exegesis, notably also by the reader of the novel, is driven ad absurdum: interpretation, explanation, and credibility implode. The frontier of the process of making sense is symbolised by South Island.

\section{Conclusion}

In this paper, I have described how islands interfere in the narration and structure of two novels by Raoul Schrott. Finis Terrae and Tristan da Cunha offer different concepts of islands and, accordingly, different modes of narration-despite their similarities. Whereas the earlier text accentuates a frail, fragmented, and almost mythical condition, narrating a perspective on the island as a fragmented mainland, deficient state, or "emblem of God's wrath" (Gillis, 2003, p. 22), Tristan evokes a plethora of island topoi. Here the idea of unity and wholeness is always doubled or counteracted by contrary motions. This doubling can be viewed as belonging to a specific concept of the island as well.

In both cases, concepts of the island are reflected in the narrative gestures. Oppositions are central to interpreting and analysing Tristan da Cunha. And fragmentation, mythical disconcertion, and the loss of meaning are pervasive in Finis Terrae. The islands-in a geographic, historical, cultural, and allegorical sense-are thus descriptive objects of the texts and at the same time determine their designs and structures.

Schrott's reflections on the many concepts of islands may not result in 'archipelagic' thinking, highlighting the agency of islands and their interconnectedness instead of their antagonistic quality, as has been encouraged by the agents of an "archipelagic turn" (Stratford et al., 2011), but they do question inherited patterns of thought. In this sense Schrott encourages "thinking with the archipelago," looking for "creative transfigurations of inheritances into something new" and challenging well-established cultural concepts (Pugh, 2013, p. 20). Especially the novel Tristan perturbs traditional island discourses by presenting them so ostentatiously, in such plenitude. Schrott does not just repeat handed-down schemes; rather, he presents them from various 
perspectives. This is not only manifest in the multiplicity of narrative voices-which is even intensified in Thomsen's narrative since Thomsen lends his voice to many historic characters-but also through the incorporation of historical documents and metafictional statements. There is no hegemonic discourse left. The centrality of the island is truly ambiguous in its inherent duality.

\section{Acknowledgements}

My sincere thanks go to Katrin Dautel and Kathrin Schödel, who organised a panel at the 2016 World Congress of the International Comparative Literature Association (ICLA) where a draft of this paper was originally presented. I also thank the referees and the editor for their helpful comments, and Anthony Mahler for editing the English text.

\section{References}

Adams, P.G. (1983). Travel literature and the evolution of the novel. Lexington: University Press of Kentucky. Böhlau, S. (2009). Literatur als "kulturelle Tauschmünze". Raoul Schrott im Gespräch mit Sarah Böhlau. In A. Bartl (Ed.), Transitträume. Beiträge zur deutschsprachigen Gegenwartsliteratur (pp. 427-436). Augsburg: Wissner.

Booy, D.M. (1958). Rock of exile: A narrative of Tristan da Cunha. New York: Devin-Adair.

Breitbarth, C. (2010). Das mehrdimensionale Spiel mit Authentizitäts- und Historizitätsfiktion in Raoul Schrotts Prosawerken. In P. Hanenberg, I. Capeloa Gil, F. Viana Guarda, \& F. Clara (Eds.), Kulturbau. Aufräumen, Ausräumen, Einräumen (pp. 335-349). Frankfurt a. M.: Peter Lang.

Dautel, K., \& Schödel, K. (2016). Introduction: Insularity, islands and insular spaces. In Insularity: Representations and Construction of Small Worlds (pp. 11-28). Würzburg: Königshausen und Neumann.

Davis, L.J. (1983). Factual Fictions. The Origins of the English Novel. New York: University of Pennsylvania Press.

Donne, J. (1987). Devotions upon emergent occasions. A. Raspa (Ed.). Oxford: Oxford University Press. Eliot, T. S. (1920). The Sacred Wood. Essays on Poetry and Criticism. London: Methuen.

Farago, J. (2014, November 12). "good artists copy; great artists steal." Retrieved from http://www.bbc.co.uk/culture/story/20141112-great-artists-steal

Fuchs, V., Wakefield, R.C., Millard, J.F., \& MacInnes, D.G. (1935). The Lake Rudolf Rift Valley Expedition 1934. The Geographical Journal, 86(2), 114-137. https://doi.org/10.2307/1786587

Gillis, J.R. (2004). Islands of the Mind. How the Human Imagination Created the Atlantic World. New York: Palgrave Macmillan.

Gillis, J.R. (2003). Taking history offshore: Atlantic islands in European Minds, 1400-1800. In R. Edmond \& V. Smith (Eds.), Islands in History and Representation (pp. 19-31). London: Routledge.

Görner, R. (2004). Inseltrauma der Unseligen. Raoul Schrotts Roman Tristan da Cunha. Literatur und Kritik, 381/282, pp. 90-92.

Grimm-Hamen, S. (2014). "Endstation Sehnsucht". Postmoderne Utopieentwürfe in Raoul Schrotts Tristan da Cunha (2003) und Christoph Ransmayrs Der fliegende Berg (2006). Germanistik in Ireland: Yearbook of the German Studies Association of Ireland, 9, pp. 57-73.

Grimm-Hamen, S. (2013). Postmoderne Spielarten des Epischen im österreichischen Gegenwartsroman. Raoul Schrotts Tristan da Cunha und Christoph Ransmayrs Der fliegende Berg. In C. Krauss \& U. Urban (Eds.), Das wiedergefundene Epos. Inhalte, Formen und Funktionen epischen Erzählens vom Beginn des 20. Jahrhunderts bis heute (pp. 109-130). Münster: LIT.

Grimm-Hamen, S. (2011). Raoul Schrotts Tristan da Cunha: Die Insel als Welt und Text. In A.E. Wilkens, P. Ramponi, \& H. Wendt (Eds.), Inseln und Archipele. Kulturelle Figuren des Insularen zwischen Isolation und Entgrenzung (pp. 99-114). Bielefeld: transcript.

Grimm-Hamen, S. (2009). Les voyageurs sédentaires de Raoul Schrott dans Tristan da Cunha oder die Hälfte der Erde. In P. Desroches-Viallet (Ed.), Construction de l'identité dans la rencontre 
des cultures chez les auteurs d'expression allemande. Le voyage immobile (Vol. 2, pp. 223-237). Saint-Étienne: Publications de l'Université de Saint-Étienne.

Hollander, R. (Ed.). (2007). Dante Alighieri. Paradiso. A verse translation by Robert and Jean Hollander. New York: Doubleday.

Höppner, S. (2007). Ultima Thule im Südmeer. Raoul Schrotts Tristan da Cunha als utopischer Roman (mit einem Seitenblick auf Finis Terrae). Raoul Schrott (Edition Text + Kritik), pp. 27-42.

Kühnel, J. (2013). Eine "verschlossene Insel. Das ist mein Tristan." Tristan-Zitate und -Allusionen in Raoul Schrotts Roman Tristan da Cunha (2003). In Tristan et Yseut, ou l'Éternel Retour. Actes du Colloque international des 6, 7 et 8 mars 2013 à la Maison de la Culture d'Amiens. (pp. 290-302). Amiens: Presses du Centre d'études médiévales, Université de Picardie-Jules Verne.

Meistersheim, A. (1997). Figure de l'îléité, images de la complexité. In D. Reig (Ed.), Île des merveilles. Mirage, miroir, mythe (pp. 109-124). Paris: L'Harmattan.

Mirzeler, M.K. (2006). The embodiment of the voyage of Sir Vivian Fuchs to the South Island in the Elmolo oral tradition. Ethnohistory, 53(1), 195-219. https://doi.org/10.1215/0014180153-1-195

Moser, C. (2005). Archipele der Erinnerung. Die Insel als Topos der Kulturisation. In H. Böhme (Ed.), Topographien der Literatur. Deutsche Literatur im transnationalen Kontext. DFG-Symposion 2004 (pp. 408-432). Stuttgart, Weimar: Metzler. https://doi.org/10.1007/978-3-476-05571-2 21

Niedermeier, C. (2003). Exerzitien der Sehnsucht. Der Standard. 6 October.

Pugh, J. (2013). Island movements: Thinking with the archipelago. Island Studies Journal, 8(1), 9-24.

Schällibaum, O. (2016). Die Kunst, Raoul Schrott (nicht) zu glauben. Variations, 24, 177-190. https://doi.org/10.3726/VAR2016 177

Schmitz-Emans, M. (2004). Die Erfindung der uralten Maschine: Raoul Schrott als Dichter und Archäologe. In D. Burdorf (Ed.), Die eigene und die fremde Kultur. Exotismus und Tradition bei Durs Grünbein und Raoul Schrott (pp. 11-47). Iserlohn: Institut für Kirche und Gesellschaft.

Schreier, D. (2003). Isolation and Language Change. Contemporary and Sociohistorical Evidence from Tristan da Cunha English. Houndmills, Basingstoke: Palgrave Macmillan. https://doi.org/10.1057/9780230505261

Schrott, R. (2016). Erste Erde. Epos. München: Hanser.

Schrott, R. (2007). Die fünfte Welt. Ein Logbuch. Innsbruck, Wien: Haymon.

Schrott, R. (2006, March 13). Dr. phil. habil. Raoul Schrott Schriftsteller im Gespräch mit Dr. Dieter Lehner. Retrieved from http://www.br-online.de/alpha/forum/vor0603/20060313.shtml

Schrott, R. (2005, March 3). Sehnsucht nach dem Anfang. Vom Wunsch, ein Stück erste Erde in den Händen zu halten - eine Odyssee durch den Nordwesten Kanadas. Die Zeit, pp. 71-72.

Schrott, R. (2003a). "Die Insel als Allegorie dessen, was Welt ist.” Ein Gespräch. In Raoul Schrott. Tristan da Cunha oder Die Hälfte der Erde. Eine Begegnung mit Autor und Roman (pp. 5-24). München, Wien: Hanser.

Schrott, R. (2003b). Tristan da Cunha oder die Hälfte der Erde. München, Wien: Hanser.

Schrott, R. (1995). Finis Terrae. Ein Nachlass. Innsbruck: Haymon.

Schrott, R., \& Dall'O, A.M. (2001). Das Geschlecht der Engel, der Himmel der Heiligen. Ein Brevier. München, Wien: Hanser.

Schutti, C. (2005). Über die Funktion einer biblischen Frauenfigur in der aktuellen Literatur. Marah in Raoul Schrotts Tristan da Cunha. Mitteilungen aus dem Brenner-Archiv, 24-25, 165-175.

Stratford, E., Baldacchino, G., McMahon, E., Farbotko, C., \& Harwood, A. (2011). Envisioning the Archipelago. Island Studies Journal, 6(2), 113-130.

Widmann, A. (2011). Die Rätsellust unseres Gehirns. Frankfurter Rundschau. 26 May. Retrieved from http://www.fr-online.de/literatur/raoul-schrott-im-interview-die-raetsellust-unseresgehirns, 1472266,8492718.html

Zeyringer, K. (2005). Raoul Schrott: Dada in Tirol, Finis Terrae, Tristan da Cunha - Literarische Erfahrungen an den Rändern. In A. Cozic \& J. Lajarrige (Eds.), Traversées du miroir: mélanges offerts à Erika Tunner (pp. 145-159). Paris: L'Harmattan. 